Original article

UDC 621.9

https://doi.org/10.24143/2072-9502-2022-1-16-21

\title{
Development of diagnostic subsystem for manufacturing active elements in instrument-making industry
}

\author{
Javanshir F. Mammadov ${ }^{1}$, Banovsha A. Valiyeva ${ }^{2}$, \\ Afat S. Huseynova ${ }^{3}$, Yegana M. Hasanova \\ ${ }^{1-4}$ Sumgait State University, \\ Sumgait,Azerbaijan, cavan62@mail.ru凶
}

\begin{abstract}
Ensuring the quality of products on the production line requires application of the automated diagnostic systems in the robotic complexes to control their performance. The aim and research problems are defined by analyzing the existing automated diagnostic systems of technical units at manufacture active elements in the instrumentalmaking industry. On an example of industrial robots working in the manufacture enterprises at instrument-making industry there were determined the sensor tools for information-measuring their moving parts and a working status of the mechatronic units, as well as a scheme of the sustainable diagnostics of automated control system of active elements of the researched technological process. To ensure the stability of an automatic diagnostic system for industrial robots working in a production module it was proposed to use general diagnostic testing tools for the automated process control system, elements for replacing faulty elements and a decision-making subsystem for diagnosing industrial robots. A hierarchical scheme of diagnostic subsystem of active elements in the automated control system of the manufacturing enterprise uinder study is given, as well as the work principals for every hierarchical level.
\end{abstract}

Keywords: diagnostic subsystems, automated control system, industrial robot, manufacture enterprise, local industrial network

For citation: Mammadov J. F., Valiyeva B. A., Huseynova A. S., Hasanova Y. M. Development of diagnostic subsystem for manufacturing active elements in instrument-making industry. Vestnik of Astrakhan State Technical University. Series: Management, Computer Science and Informatics. 2022;1:16-21. (In Russ.) https://doi.org/10.24143/20735529-2022-1-16-21.

Научная статья

\section{Разработка диагностической подсистемы производства активных элементов приборостроительной промышленности}

\author{
Джсаваншир Фирудин Мамедов ${ }^{1 凶}$, Бановща Аслан Валиева ${ }^{2}$, \\ Афат Судеф Гусейнова ${ }^{3}$, Йегана Мирдамат Гасанова ${ }^{4}$ \\ ${ }^{1-4}$ Сумгаитский государственный университет, \\ Сумгаит, Азербайджан, саvап62@mail.ru
}

\begin{abstract}
Аннотация. Обеспечение качества продукции, производимой на производственной линии, требует использования автоматизированных систем диагностики промышленных роботов в робототехнических комплексах для контроля их производительности. На основе анализа существующих автоматизированных систем диагностики технических систем в приборостроении определены цель и исследовательские вопросы статьи. На примере промышленного робота, работающего на производственных предприятиях приборостроительной отрасли, определены сенсорные средства для информационного измерения его движущихся частей и рабочего состояния мехатронных узлов, а также предложена схема устойчивой диагностики автоматизированной системы управления активными элементами исследуемого технологического процесса. Для обеспечения устойчивости автоматической системы диагностики промышленных роботов, работающих в производственном модуле, предлагается использовать общие средства диагностического тестирования автоматизированной системы управления технологическими процессами, элементы замены неисправных элементов и подсистему принятия решений по диагностике промышленных роботов. Предложена иерархическая схема подсистемы диагностики активных элементов автоматизированной системы управления исследуемого производственного предприятия, а также приведены принципы работы для каждого иерархического уровня.
\end{abstract}

Ключевые слова: диагностические подсистемы, автоматизированная система управления, промышленный робот, производственное предприятие, локальная промышленная сеть

(C) Mammadov J. F., Valiyeva B. A., Huseynova A. S., Hasanova Y. M., 2022 
Для цитирования: Мамедов Дж. Ф., Валиева Б. А., Гусейнова А. С., Гасанова Е. М. Разработка диагностической подсистемы производства активных элементов приборостроительной промышленности // Вестник Астраханского государственного технического университета. Серия: Управление, вычислительная техника и информатика. 2022. № 1. С. 16-21. https://doi.org/10.24143/2072-9502-2022-1-16-21.

\section{Introduction}

To obtain complete information about the internal state of the information-measuring, control, regulation and automation control system (ACS) of the manufacture enterprises, their active elements like an industrial robots (IR) which provides automation of production processes and control its operations, it is necessary to automate the accurate and reliable functions of the diagnostic system. Analysis of the current state of the automated diagnostic systems of the manufacture active elements and also IR used in the enterprises of the instrument-making industry shows that one of the important issues is to check, evaluate and make the right decision during the operation of the mechatronic parts of IR. Timely automated diagnostics of IR is significantly reduced due to the reduction of time for the recovery of its mechanical and electronic parts. The use of automated diagnostic systems for IR in robotics complexes used in large manufacturing enterprises is especially relevant, as it is important to ensure the quality of products manufactured and transported on the production line, to monitor the performance and internal condition of IR. The use of IR [1,2] automated diagnostic system (ADS), which performs important operations and serves complex and expensive complex equipment, especially in instrument-making enterprises, is becoming increasingly important.

\section{Problem solving}

The procedure for diagnosing active elements of the manufacture enterprises like IR consists of two stages: checking the performance of IR and searching for faults in the mechatronic parts. For this purpose, it is first required to perform a technical diagnostic (TD) of the IR included in the ADS. With the help of TD is to ensure productivity by timely recognition of IR rejections and eliminating the causes of their occurrence. One of the important methods used in the technical diagnosis of IR and others active elements of the manufacture enterprises is the test method [3, pp. 126-145].

A comprehensive functional analysis is performed to ensure the technical diagnosis of ADS by monitoring the current state of IR mechatronics and the current quality of the manipulated product. Functional analysis of technical diagnostics includes the occurrence of noise or vibration in the combined kinematic points of IR, delays in the process of technological operation, and excess power consumption of the control system [4, pp. 77-98]. Monitoring, recording and decision-making of these indicators are ensured by means of sensors and control diagnostic system, respectively.

Diagnosis of the current state of the mechatronics of IR is based on the following previously accepted indicators for operations:

- the sounds generated between the kinematic displacement points of IR must be in the received sound range. It should be noted that if the lubrication process between the kinematic points is not carried out in time during the operation of IR, such failures occur, which shortens the longevity of the mechanical parts of IR;

- vibration in the kinematic displacement points of IR. It should be noted that during the operation of IR, wear, loosening and damage occur at the joints between the kinematic points, which reduces the reliability of the technological operations of the IR as whole;

- the power supply of IR must be in the required range. It should be noted that high humidity in the workplace, malfunctions in the control electronics, communications, and their welding parts can be reasons for power outages or substandard IR.

Based on the permissible needs and causes, the above faults, can occur in the positions of the dynamic structure of the IR (at the junction of the moving points of the IR - at the point of operation of the transmissions) and the control system, the speakers, vibration control system and power. Informationmeasuring instruments for diagnostics (IMID) of complex moving arm, its gripper and theirs control functions on IR are installed at the top level of the automated control subsystem of IR. The analysis of the technical characteristics of the moving parts of the IR (line of IR arm, rotational displacements, opening and closing of the handle, etc. operations) is carried out with the help of IMID [5]. By creating a technical interface with the automated control subsystem of IR, IMID allows to solve the problem of predicting the reliability of technological operations of the robot.

During the diagnostics of the blocks of the automated control subsystem of IR, the defects of the electronic parts are localized and the corresponding elements are tested. The resulting diagnostic kernel loads the current data, provides test effects at the input of the control unit being tested, and at the output it queries the answers, compares the answers with the reference values, analyzes and displays the results.

Diagnosis of blocks of the automated control subsystem of IR is carried out before and after the assembly of the elements. Based on the results of the alternative control of the control subsystem, its faulty element is determined and the "faulty" condition of the board is deter- 
mined for two groups. When a group of faults is indexed, a fault-type diagnostic file related to the kinematic point of IR is formed. For example, in the event of a short circuit or cable breakage in the automated control subsystem of IR, the number of points on the board is given, and the type and denomination of the element is given for faulty electronics parts. During the operation of the diagnostic system, self-monitoring takes place through a special program and a reference board [6].
To ensure the sustainability of the automated diagnostics of IR operating in the production module, it is proposed to use the general diagnostic testing tools (GDTT) of the automated process control system, the replacement elements of the defective elements (REDE) and the IR diagnostic decision-making subsystem (IR_DDMS) (Fig. 1).

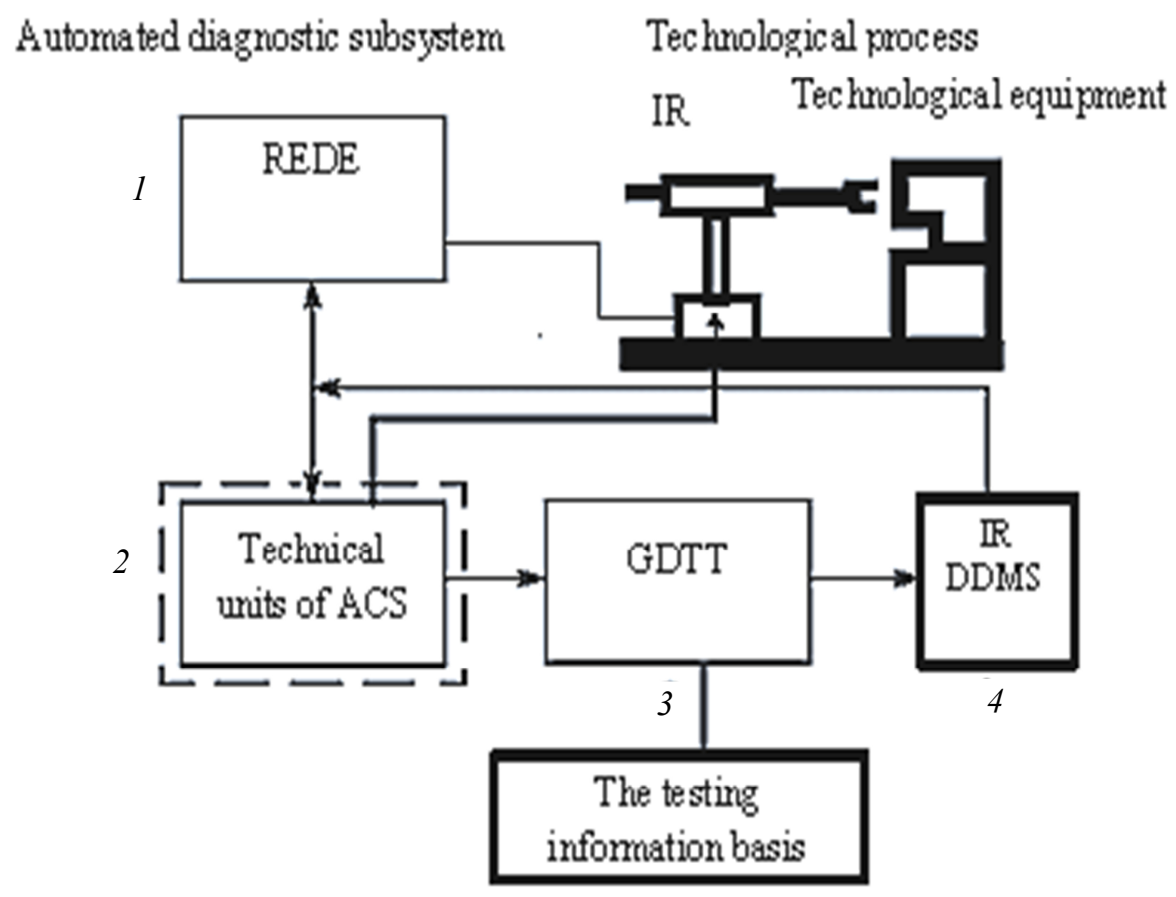

Fig. 1. Scheme of sustainable diagnostics of ACS of active elements of the technological process: 1 - replacement elements of the defective elements; 2 - technical units of ACS; 3 - general diagnostic testing tools; 4 - IR diagnostic decision-making subsystem

In the instrument-making manufacture island (the investigated technological process), robotic complexes are served by digital software-controlled technological equipment. In order to increase the service life of technological equipment in this process, their diagnostics must also be provided. The information connections of the digital equipment-controlled diagnostic system are provided with measuring instruments, technical interface (TI), diagnostic-control node (DCN), technological equipment status indicator (TESI) and technological equipment decisionmaking subsystem (TE DMS) [7]. Automated diagnostics of process equipment is required to be carried out in one turn or after the preparation (processing) of a batch of parts. In this case, the accuracy of operations of technological equipment, rigidity, power supply, oil content of mechanical parts, etc. procedures are reviewed, evaluated and decided upon.

The researched manufacture island is formed from the steel plate heating furnace, industrial robots serving the furnace and mechanical processing module, automatic transport system, steel plate polishing machines. For providing diagnostic prosedures in that manufacture island, automation scheme of the diagnostic system based on the automated control system is proposed to control the compatibility of the mentioned active elements (Fig. 2).

The proffered automated scheme of diagnostic subsystem of active elements included to ACS of the researched manufacturing enterprise is built on the pricipals of hierarchical level. Also it is given work principals for every hierarchical level of the automated scheme of the diagnostic system. 


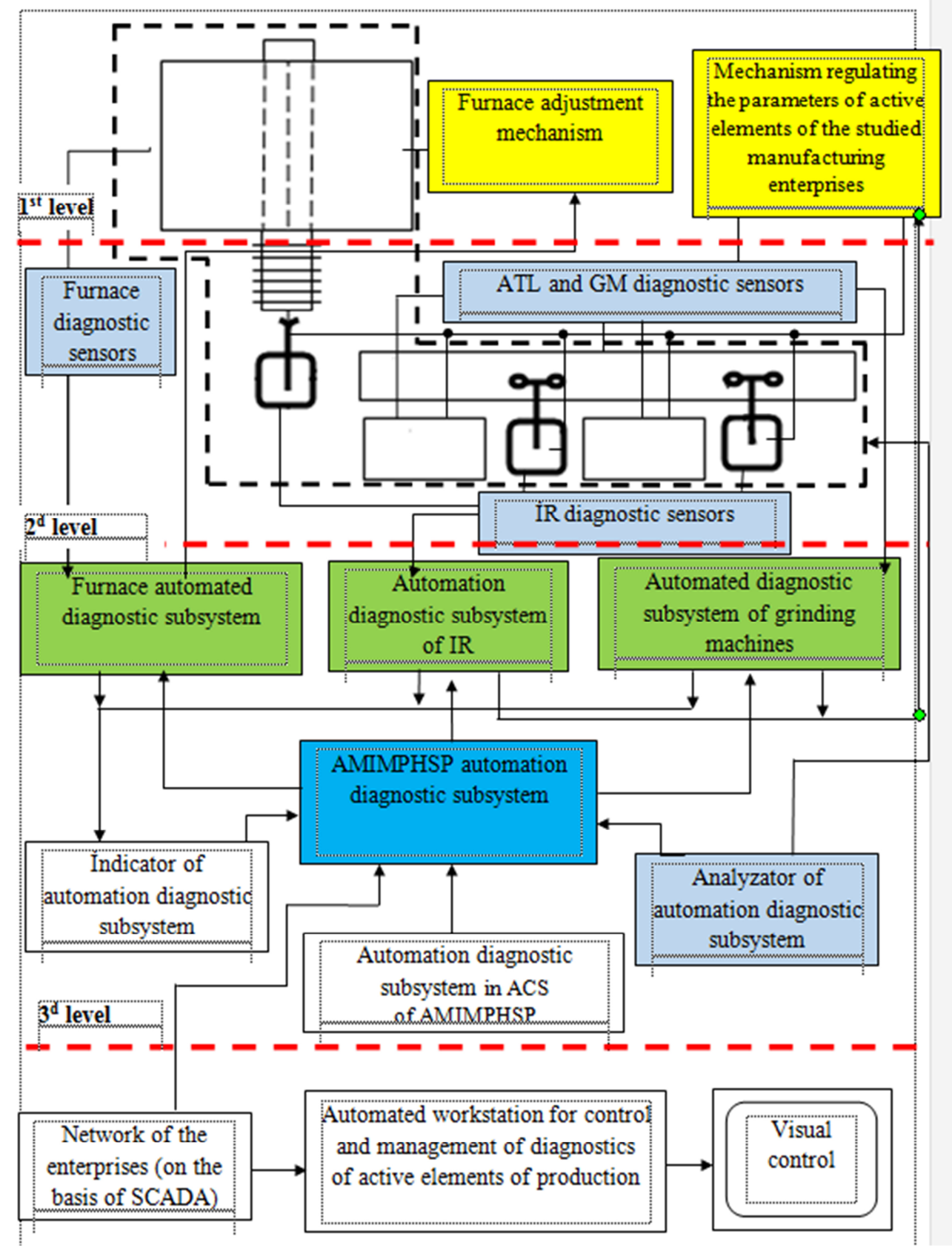

Fig. 2. Hierarchical scheme of diagnostic subsystem of active elements at ACS of the manufacturing enterprise

The control and monitoring functions of the automated manufacture island of mechanical processing and heating steel plates (AMIMPHSP) require diagnostics of the furnace, automatic transport system, steel plate polishing machines and industrial robots, and prompt troubleshooting. In order to increase the service life of AMIMPHSP, to ensure the production of quality products and the reliability of the management system, the issue of developing a generalized automated diagnostic system is raised. The automation scheme of the diagnostic system on the basis of ACS of AMIMPHSP is divided into hierarchical levels.
Level 1 Information-measuring elements of AMIMPHSP diagnostic system operating in production modules, heating aluminum plate, automatic transport lines (ATLi), grinding machines (GMi) and industrial robots (IRi). A special diagnostic analyzer (DA) is used in the active elements of the production module to perform complex level 1 diagnostic operations. DA analyzes the current technical characteristics of IRi, GMi, ATLi and the technical characteristics of the furnace, the accuracy of displacements, the accuracy of geometric parameters, the evaluation of kinematic parameters and creates an interface with the control unit of the diagnostic system at a high hierarchy level. 
The interface between the DA and the programmable logic controllers of the diagnostic subsystem provides a prediction of the reliability of the functions of the active elements of production.

At level 1, regulatory tools are used that affect the accuracy of the technological operations of the production and its active elements, the reliability of the functions of the process control system and, in general, the flexibility and required productivity of production. Regulation of the required temperature in the production furnace with the help of regulating elements in technical means on external and internal control influences in the technological process (furnace temperature, dimensions, weight of aluminum plate, speed of automatic transport lines and degree of polishing of positioning error, etc.); regulation of the degree of polishing of the upper surface of the aluminum plate of the polishing machine, regulation of the linear and angular displacements of industrial robots; automatic transport speed adjustment functions are provided.

Level 2 refers to automated diagnostic subsystems belonging to each technical unit of AMIMPHS (on the basis of programmable logic controllers (PLC), the corresponding blocks are shown in green in Figure 5). Level 1 from the sensor elements of AMIMPHS diagnostic system on the current state of the operating modes of technical units (furnace temperature mode, ATLi movement speeds and positioning intervals, degree of polishing of aluminum plates on polishing machines, accuracy of their parts, accuracy of displacement movements of industrial robots) the data is transmitted to the input of PLC of the diagnostic subsystem. In this

case, an automated technical assessment is made and a decision is made on the operating status of each active element in the internal memory system of the PLC on the basis of the logic software of individual diagnostics. In addition to the functions of the diagnostic subsystem, the program tests the current state of the execution mechanisms of the active elements of the production modules under study. When the operating mode of each active element of the production modules is violated, the status indicator is activated.

At level 3, the active elements of production are connected to the server of the local industrial network of the automated workplace and control node to provide control and management of the automated diagnostic process. Automation of management and control functions of the diagnostic system with the help of a local industrial network server is provided with the help of SCADA.

\section{Conclusion}

1. It was determined sensor tools for informationmeasuring of its movement parts and its working status of mechatronic units, and also proffered the scheme of means of sustainable diagnostics of automated control system of active elements of the researched technological process.

2. Hierarchical scheme of diagnostic subsystem of active elements at ACS of the researched manufacturing enterprise is proffered, and also it is given work principals of every hierarchical level of the diagnostic subsystem.

\section{References}

1. Evtushenko Iu. G., Dianov V. N., Severtsev N. A. Rol' $i$ mesto sboev $v$ informatsionnoi bezopasnosti sovremennykh slozhnykh sistem [Role and place of failures in information security of modern complex systems]. Fundamental'nye problemy sistemnoi bezopasnosti. Moscow, Vuzovskaia kniga Publ., 2011. Iss. 3. P. 235.

2. Dianov V. N., Liuminarskaia E. S., Belousov I. M., Duseev S. G., Kholina M. N. Sistema upravleniia antropomorfnym robotom [Control system for anthropomorphic robot]. Patent RF № $124623 ; 02.10 .2013$.

3. Safarbakov A. M., Luk'ianov A. V., Pakhomov S. V. Osnovy tekhnicheskoi diagnostiki: uchebnoe posobie [Fundamentals of technical diagnostics: teaching aids]. Irkutsk, Izd-vo IrGUPS, 2006. 216 p.
4. Makarov I. M., Lokhin V. M., Romanov M. P., Man'ko S. V. Intellektual'nye sistemy upravleniia [Intellectual control systems]. Moscow, Nauka Publ., 1999. 212 p.

5. Bigus G. A., Daniev Iu. F., Bystrova N. A., Galkin D. I. Diagnostika tekhnicheskikh ustroistv [Diagnostics of technical devices]. Moscow, Izd-vo MGTU im. N. E. Baumana, 2014. $615 \mathrm{p}$.

6. UZ-skaner-defektoskop USD-60-8K (NPTs «Kropus») [Ultrasonic scanner-flaw detector USD-60-8K (SPC Kropus)]. Available at: https://kropus.com/products/usound/ ucd60-8k.php (accessed: 15.09.2021).

7. Mammadov J. F., Tagiyeva T. A., Akhmedova S. M., Aliyeva A. Interface for intelligence computing design and option of technical systems. Intelligent Control and Automation, 2015, vol. 6, no. 4, pp. 289-294.

\section{Список источников}

1. Евтушенко Ю. Г., Дианов В. Н., Севериев Н. А. Роль и место сбоев в информационной безопасности современных сложных систем // Фундаментальные проблемы системной безопасности. М.: Вузов. Книга, 2011. Вып. 3. С. 235.

2. Пат. РФ № 124623. Система управления антропоморфным роботом / Дианов В. Н., Люминарская Е. С., Белоусов И. М., Дусеев С. Г., Холина М. Н.; заявл. 05.02.2012; опубл. 02.10.2013; Бюл. № 4.
3. Сафарбаков А. М., Лукьянов А. В., Пахомов С. В. Основы технической диагностики: учеб. пособие. Иркутск: Изд-во ИрГУПС, 2006. 216 с.

4. Макаров И. М., Лохин В. М., Романов М. П., Манько С. В. Интеллектуальные системы управления. М.: Наука, 1999. $212 \mathrm{c.}$

5. Бигус Г. А., Даниев Ю. Ф., Быстрова Н. А., Галкин Д. И. Диагностика технических устройств. М.: Изд-во МГТУ им. Н. Э. Баумана, 2014. 615 с. 
6. УЗ-сканер-дефектоскоп УСД-60-8К (НПЦ «Кропус»). URL: https://kropus.com/products/usound/ucd608k.php (дата обращения: 15.09.2021).
7. Mammadov J. F., Tagiyeva T. A., Akhmedova S. M., Aliyeva A. Interface for intelligence computing design and option of technical systems // Intelligent Control and Automation. 2015. V. 6. N. 4. P. 289-294.

The article is submitted 24.11.2021; approved after reviewing 08.12.2021; accepted for publication 22.12.2021 Статья поступила в редакцию 24.11.2021; одобрена после рецензирования 08.12.2021; принята к публикации 22.12.2021

\section{Information about the authors / Информация об авторах}

Javanshir F. Mammadov - Doctor of Technical Sciences; Head of the Department of process Automation; Sumgait State University; Sumgait, 43rd quarter; cavan62@mail.ru

Banovsha A. Valiyeva - doctorate of the Faculty of Engineering; Sumgait State University; Sumgait, 43rd quarter; veliyeva.67@bk.ru

Afat S. Huseynova - Assistant Professor of the Department of Information and Computer Technics; Sumgait State University; Sumgait, 43rd quarter; cavan62@mail.ru

Yegana M. Hasanova - doctorate of the Faculty of Mathematics, Department of Informatics; Sumgait State University; Sumgait, 43rd quarter; cavan62@mail.ru
Джаваншир Фирудин огль Мамедов - доктор технических наук; заведующий кафедрой автоматизации процессов; Сумгаитский государственный университет; Сумгаит, 43-й квартал; cavan62@mail.ru

Бановща Аслан гызы Валиева - докторант инженерного факультета; Сумгаитский государственный университет; Сумгаит, 43-й квартал; veliyeva.67@bk.ru

Афат Судеф гызы Гусейнова - доцент кафедры информационной и компьютерной техники; Сумгаитский государственный университет; Сумгаит, 43-й квартал; cavan62@mail.ru

Йегана Мирдамат гызы Гасанова - докторант факультета математики, кафедры информатики; Сумгаитский государственный университет; Сумгаит, 43-й квартал; cavan62@mail.ru 